$1-1-2001$

\title{
The Georgia Immigration Pardons: A Case Study in Mass Clemency
}

Elizabeth Rapaport

University of New Mexico - School of Law

Follow this and additional works at: https://digitalrepository.unm.edu/law_facultyscholarship

Part of the Law and Society Commons

\section{Recommended Citation}

Elizabeth Rapaport, The Georgia Immigration Pardons: A Case Study in Mass Clemency, 13 Federal Sentencing Reporter 184 (2001).

Available at: https://digitalrepository.unm.edu/law_facultyscholarship/81

This Article is brought to you for free and open access by the UNM School of Law at UNM Digital Repository. It has been accepted for inclusion in Faculty Scholarship by an authorized administrator of UNM Digital Repository. For more information, please contact amywinter@unm.edu, Isloane@salud.unm.edu,sarahrk@unm.edu.

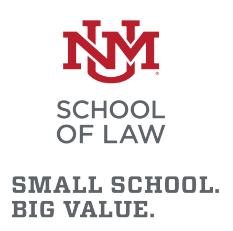

BIG VALUE. 


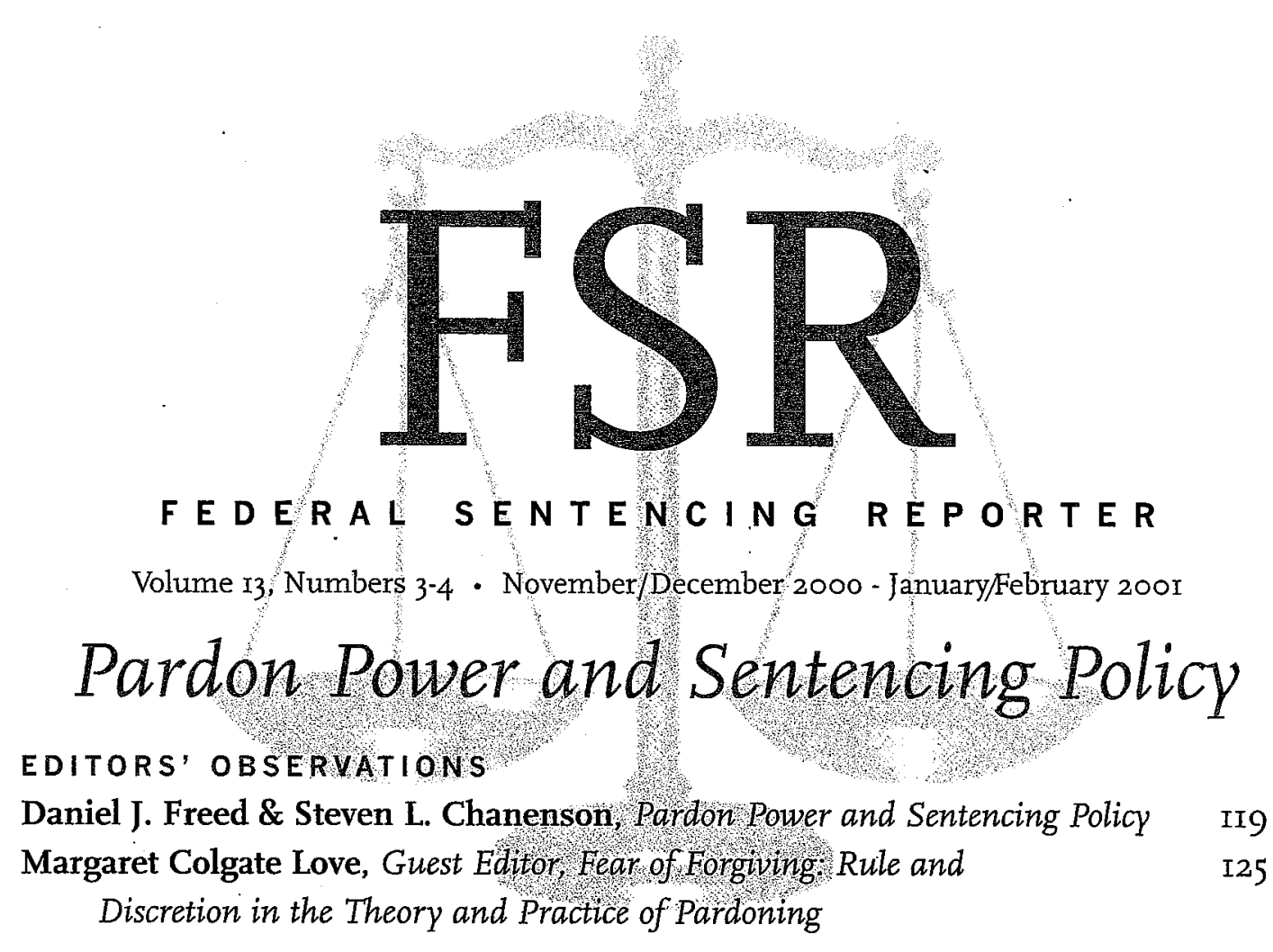

ARTICLES

A. Guidance for Pardons

David Tait, Pardons in perspective: the role of forgiveness in criminal justice $\quad 134$

Charles Shanor \& Marc Miller, Pardon Us: Systematic Presidential Pardons 139

John Harrison, Pardon as Prerogative $\quad$ I47

Daniel T.Kobil, Should Clemency Decisions be Subject to a Reasons Requirement? I5O

John R. Steer \& Paula Biderman, Impact of the Federal Sentencing Guidelines $\quad$ I54

on the Presidential Power to Commute Sentences

B. Reflections on the Clinton Pardons

Kathleen Dean Moore, Mr. President, Misusing This Power is Unpardonable $\quad$ I59

David S. Doty, Clemency: A View from the Bench of Two Commutations I6I

Deborah Devaney, $A$ Voice for Victims: What Prosecutors Add to the Process $\quad I_{3}$

David M. Zlotnick, Federal Prosecutors and the Clemency Power I68

Evan P. Schultz, Does the Fox Control Pardons in the Henhouse?

Brian M. Hoffstadt, Guarding the Integrity of the Clemency Power $\quad \mathrm{I} 80$

C. Roads Less Traveled

Elizabeth Rapaport, The Georgia Immigration Pardons $\quad$ I84

Mary Price, The Other Safety Valve: Motions under 18 U.S.C. $\int 3582($ c)(1)(A) I88

APPENDIX: Table of Contents $\quad$ - $\quad$ I92

A. Rules of the Pardon Process : $\quad$ I93

B. Historical Snapshots of the Process 198

C. Effect of a Pardon : 2 2II

D. Clinton Era Cases and Comments 225

The Federal Sentencing Reporter is published for

the Vera Institute of Justice by the University of California Press 


\section{The Georgia Immigration Pardons: A Case Study in Mass Clemency}

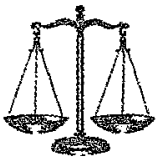

\section{ELIZABETH RAPAPORT}

Professor of Law, University of New Mex. ico. I would like to express my gratitude to Gabriel J. Chin, Cary Copeland, and Barbara Schwartz for generously sharing their knowledge of immigration law, and to Margaret Love for her deft editing. I am also grateful to the University of lowa College of Law, and especially to Eric $\mathrm{G}$.

Andersen, for their hospitality to me, a teacher.visitor in the summer of 2001, dur ing which this article was written. I would also like to thank Michelle Hurley for research assistance in the preparation of this article. Credit for any errors or infelicities is my own.
The 1996 Illegal Immigration Reform and Immigrant Responsibility Act (IIRAIRA) enlarged the class of aliens subject to mandatory deportation as "aggravated felons" under the Immigration and Nationality Act." Included in IIRAIRA's expansive definition of an "aggravated felony" are misdemeanor thefts and assaults, when they result in a I2 month sentence, served or suspended. ${ }^{2}$ Both the Clinton and Bush administrations pushed the position that persons convicted before the law's enactment are subject to its penalties because its effect is retroactive. ${ }^{3}$ Before IIRAIRA took effect, alien misdemeanants could seek waiver of deportation from immigration judges, appeal adverse decisions to the Board of Immigration Appeals, petition for review to the Attorney General, and ultimately challenge their deportation in federal district court. ${ }^{4}$ But under IIRAIRA as administered by the Clinton and Bush Justice Departments, there is no provision for making exceptions, and no right to review in any forum. There is only one way of avoiding deportation where a non-citizen has at any time in the past been convicted of an offense triggering removal, and that is to obtain a pardon.

Over the I5-month period ending in June of 200I, the Georgia Board of Pardons and Parole granted I 8 pardons to permanent resident aliens who had suddenly found themselves subject to deportation under IIRAIRA. ${ }^{6}$ Recipients of these pardons included people who had lived in the United States for many years, were married to U.S. citizens, and who had U.S. citizen children. Some of them had been convicted of very minor offenses years before IIRAIRA's enactment.

The 5 -member Georgia Board that stepped in to prevent IIRAIRA from wreaking havoc in the lives of alien misdemeanants has exclusive clemency authority in Georgia.? It has been unanimous in support of its decision to extend relief on a class-wide basis. Thus far it appears that no other state clemency authority has responded to IIRAIRA deportations with systematic relief similar to that provided by the doughty Georgia Board. Yet the Georgia experience provides some interesting insights into the function of pardon in a contemporary setting that may have more general application.

Genesis and Scope of the Georgia Immigration Pardons The education of the citizenry of Georgia to the dire immigration consequences of a misdemeanor conviction under IIRAIRA began in January 2000 when the Atlanta Journal and Constitution published a story about the threatened deportation of a lawful permanent resident alien named Mary Anne Gehris. ${ }^{8}$ Gehris was a
German-born 34-year-old married mother of two U.S. citizen children. She originally came to the United States with her adoptive parents before her second birthday. It was Gehris's application for U.S. citizenship in 1999 that precipitated the threat of deportation based on a I2-year-old misdemeanor conviction for pulling another woman's hair in a fight over a man. In her early twenties at the time of conviction for simple battery, Mary Anne Gehris had been sentenced to a suspended I2-month sentence and placed on probation.?

The Atlanta newspaper followed its report on the Gehris case with extensive coverage of the plight of other comparatively innocuous alien misdemeanants caught up in the inexorable machinery of IIRAIRA. ${ }^{\text {10 }}$ Georgians learned that hundreds of people from across the nation had been deported for minor crimes as a result of IIRAIRA." They learned that fellow Georgians facing deportation included an Ethiopian who had stolen a chicken sandwich, a Nigerian who had stolen two boxes of donuts, and a second Nigerian convicted of stealing a \$ 5 baby outfit. These stories were retold in the newspaper along with those of an English teenager threatened with deportation for underage drinking and a Laotian man who was convicted of shoplifting a pair of blue jeans when he was a teenager. ${ }^{12}$ Some of these cases involved people who, like Mary Anne Gehris, had been brought to this country as young children, could not speak the language of their native countries, and had no relatives or friends to whom to return. Some faced very difficult choices about the futures of their own citizen children.

In response to this publicity, the Board took the initiative to inform the.immigrant community that it would entertain pardon applications from aliens who would otherwise be deported because of their misdemeanor convictions. Within hours of reading a newspaper account of Gehris's unhappy attempt to become a US citizen, the Assistant Director of the Board's Clemency Division telephoned Gehris's attorney to convey this news. ${ }^{\text {r3 }}$ The message to Gehris - and by extension to the entire Georgia immigrant community - was that a misdemeanant with an otherwise clean record was eligible for a pardon to avert deportation.

In the months that followed, the Board deployed its discretionary authority decisively and creatively to provide systematic relief to lawful resident aliens who had been convicted of minor offenses but were otherwise productive and law-abiding members of the community. ${ }^{4}$ The Board's major procedural innovations were to open its pardon process to misdemeanants, and 
to waive the otherwise applicable eligibility waiting period. ${ }^{15}$ Its actions proved popular with the media and public. ${ }^{16}$ Cases like that of Mary Anne Gehris were portrayed as visiting absurd and frightening consequences on law-abiding residents and their families.

Of 139 immigration pardons granted by the Georgia Board during the 15 month period between March 2000 and June 2001,138 went to misdemeanants. ${ }^{17}$ The story of the single felon to be pardoned is also instructive. Dong Jin Park was a respected Korean businessman in his mid-4os, a deacon in his church, and a twenty-year resident of Georgia. ${ }^{18} \mathrm{His}$ three teenage daughters had been born in the United States. In 1996 Park had been convicted of aggravated assault upon an employee, perpetrated during a brawl after a night of heavy drinking. He had been sentenced to three years in prison and served his time. The Korean community in Georgia, approximately 50,000 persons strong, engaged in unprecedented political activism in its eventually successful drive to see Park pardoned.9

At the same time, other Board policies affecting aliens remained unchanged, and it continued to cooperate fully with the Immigration and Naturalization Service (INS) to accomplish the deportation of alien offenders. Nor was the Board willing, with the exception of the Dong Jin Park case, to waive its otherwise applicable procedural rules by which felons seeking a pardon must have completed their sentences and lived crime-free for five years thereafter..$^{20}$ As a result, only one or two alien felony offenders have been able to avoid deportation through the routine operation of Georgia's clemency procedures. ${ }^{21}$

\section{Related Responses to IIRAIRA}

While the Georgia Board was adapting its pardon procedures to accommodate alien misdemeanants, efforts were underway in the legislative and judicial branches of the state to alleviate the impact of IIRAIRA's mandatory deportation provisions on immigrant communities. The Georgia legislature enacted a statute requiring a judge to warn alien offenders who are considering a guilty plea that one consequence of conviction may be deportation..$^{22}$ Not long thereafter, the Georgia Supreme Court upheid a superior court judge's grant of habeas relief to a Romanian shoplifter who had not been so warned. ${ }^{23}$ Some Atlanta judges began to sentence permanent resident aliens to II months and 29 days, rather than impose a I2-month sentence that would trigger deportation. ${ }^{24}$ The Georgia delegation to Congress was also active in efforts to moderate IIRAIRA.25

While its pardons provided the most immediate form of relief for individuals threatened with deportation, the Georgia Board also played an active role in the law reform effort. In March of 2000 , in a letter signed by all five of its members, the Georgia Board took the unusual step of writing to Senator Max Cleland, urging him to work to bring just standards and procedures into immigration law. ${ }^{26}$ The Board's support for reform of IIRAIRA was evidently motivated not simply by humanitarian considerations, but also by a desire to ease the administrative burden of its unsought role as the routine arbiter of the fate of non-citizen misdemeanants."

Meanwhile, the Bush Justice Department, like its Clinton predecessor, committed to a policy of prompt and certain deportation of criminal aliens, continued to press interpretations of IIRAIRA that close off any avenue of administrative or judicial relief. ${ }^{28}$ The government has remained steadfast in this policy commitment despite public antagonism to IIRAIRA deportation policies in Georgia and elsewhere. ${ }^{29}$

\section{Lessons of the Georgia Immigration Pardons}

The Georgia Board enters a small company of executive clemency authorities who have granted "mass clemency" in response to laws regarded as overly harsh or otherwise unjust..30 Early in the twentieth century, Governor Donaghey of Arkansas pardoned hundreds of convicts because he opposed the convict labor system. ${ }^{3 x}$ In the early ig6os, President John Kennedy pardoned more than one hundred drug offenders serving mandatory minimum sentences..$^{32}$ More recently, Governor Toney Anaya commuted the sentences of all five persons on death row in New Mexico before leaving office in I986.33 Governor Richard Celeste of Ohio commuted the sentences of eight death row inmates at the end of his term. ${ }^{34}$ Several states, including Ohio and Florida, instituted comprehensive clemency reviews and releases for women prisoners who killed their batterers, but were legally barred from mounting battered woman defenses at the time of trial. ${ }^{35}$

For those who believe that the traditional discretionary clemency has outlived its usefulness, the Georgia immigration pardons should occasion further reflection. Discretionary authority allowed the Board to correct manifest injustice not otherwise subject to redress. To avoid the indiscriminate and relentless operation of a draconian law, the Board suspended its ordinary rules of practice. It used its discretionary pardon power in an expansive and creative way to avert a severe legal penalty, and not simply to restore individual reputation and civil rights as had been its normal past practice. ${ }^{36}$

The Georgia immigration pardons probably represent something close to the outer limits of the capacity of clemency to rectify the effects of an unjust law. Clemency-cannot substitute for genuine law reform, and can at best perform a holding action until comprehensive and permanent relief is forthcoming from the legislature. The relief offered convicted misdemeanants by the Georgia Board has - with one exception - not been extended to perhaps equally deserving felons, who must satisfy the ordinary criteria for eligibility regardless of the nature of their crimes, subsequent rehabilita- 
tion, length of residency in the United States, or impact on family and dependents.

One could speculate about whether lodging the clemency authority in an elected official or in an appointed board relatively insulated from electoral politics would be more likely to produce an authority willing to use its power liberally in response to circumstances like the IIRAIRA deportations. Would a governor be more able to expand a program like the Board's to include deserving felons? He or she would be better positioned than a board to educate public opinion. Or would a governor be less likely to offer the mass relief the Board has granted to misdemeanants? He or she would be less insulated from possible adverse political consequences of such action. In any event, in no other state has the clemency authority asserted its power to spare immigrants as has the Georgia Board, regardless of constitutional variations in the allocation of clemency authority.

\section{Conclusion}

The number of mass clemencies in this country is not large, and the history of such executive actions has yet to be written. Mass clemencies, like all uses of the clemency power, have the potential to serve the exemplary function of focusing the attention of the public and legislators on the case for law reform. The most enduring effects of the Georgia immigration pardons, beyond their immediate effects on those whose deportations have been averted, may be made known through the actions of the Georgia congressional delegation and other agents of immigration law reform. Another possible result of great signifcance would be realized if other state clemency authorities were to join the Georgia Board of Pardons and Parole in systematically pardoning immigrants whose deportation would work grave injustice.

\section{Notes}

1 The IIRAIRA provides for the "removal" of aliens convicted of certain offenses, in an Orwellian avoidance of the more familiar term that might otherwise evoke sympathy in a nation populated by waves of immigrants. I will use the term "deportation" as well as the neologism "removal," out of respect for American language and traditions. IIlegal Immigration Reform and Immigrant Responsibility Act of 1996, Pub. L. no. 104-208, Div. C, 110 Stat. 3009-546.

${ }^{2}$ See 8 U.S.C. $\$ 1101$ (a) 43 (2001).

3 Div. C. of the Illegal Immigration Reform and Immigrant Responsibility Act. After this article was submit. ted, the Supreme Court rejected the stance of the Bush and Clinton administrations that IIRAIRA imposed automatic and retrospective deportation on such immigrants in INS v. St. Cyr, No. 00-767, 2001 WL 703922 (U.S. June 25, 2001, and Colcano-Martidez v. INS, No. 00-1011, 2001 WL 703993 (U.S. June 25, 2001).

${ }^{4}$ See Nancy Morawetz, Understanding the Impact of the 1996 Deportation Laws and the Limited Scope of Proposed Reforms, 113 Harv. L. Rev. 1936 (2000) for a detailed comparison of IIRAIRA and the regime it superseded.

${ }^{5}$ See supra note 3 infra note 28 . Div. C. of the Illegal Immigration Reform and Immigrant Responsibility Act:

- Office of Public Information, Georgia Board of Par. dons and Parole, May 31, 2001, facsimile communication to the author. During all of 1999, the Georgia Board granted only one pardon to a permanent resident alien.

'Georgia's clemency authority is lodged exclusively in a five member Board appointed by the governor to serve seven-year terms subject to confirmation by the state senate. See Ga. Const. art. IV, § 2. The transfer of clemency power from the governor to the Board was accomplished in 1943 by a constitutional refer. endum. See State of Georgia Board of Pardons, History (June 1,2001), available at www.pap.state.ga.us/ history.html. This institutional reform was a response to questionable pardon practices in some past gubernatorial administrations. Governor Ellis Arnall was the chief architect of the reform, aimed at insulating clemency decisions from political pressures. Tele. phone Interview with Walt Davis, Assistant Director, Clemency Division of the Georgia Board of Pardons and Parole (June 11, 2001).

${ }^{8}$ Mark Bixler, Atlanta Journal And Constitution, Past's Pull: Old Incident Threatens Deportation. Jan. 10,2000, at $1 \mathrm{~B}$. The Gehris story had been the subject of a column by Anthony Lewis in the New York Times the previous day. See 'This has Got Me in Some Kind of a Whirlwind,' New YoRK Times, Jan. 8, 2000, at A13.

${ }^{9}$ Mark Bixler, 'I pledge allegiance...; She Goes From Deportation List to Citizenship, ATLANTA JOURNAL AND CONSTITUTION, February 10, 2001, at $1 \mathrm{~A}$ :

${ }^{10}$ Between January 10,2000 , the date on which the Atlanta Journal and Constitution carried its first story about Mary Anne Gehris, and February 10, 2001, the date on which it announced she had become a citi. zen, the newspaper carried at least 14 stories or opinion pieces detailing and deploring the impact of IIRAIRA on immigrants convicted of minor crimes and on rehabilitated felons.

${ }^{11}$ The INS estimated that, "the number of people deported nationally for petty crimes such as. shoplifting is "in the hundreds." Mark Bixler, Deportation Threat May Be Near End, ATLANTA JOURNAL AND ConstituTION, Jan. 11, 2001, at $1 B$

${ }^{12}$ Mark Bixler, Global Atlanta: Easing up on Deportation: Every Monday, a Look at Our Changing Communities, AtLANTA Journal AND Constitution, Aug. 28, 2000, at 1B, and Milo Ippolito, State High Court's Ruling May Aid Immigrants; Judges Have Leeway to Avert Deportation, ATLANTA JOURNAL AND CONSTITUTION, Jan. 23, 2001, at 1JJ.

${ }^{13}$ Mark Bixler, Covington Hair Tugger Pardoned, ATLANTA Journal ANd Constitution, Mar. 3, 2000, at 1A; Telephone Interview with Walt Davis, Assistant Director, Clemency Division of the Georgia Board of Pardons and Parole (June 1, 2001).

${ }^{14}$ From January 1, 2000 to June 1, 2001, the Board received 257 applications for pardons to avert deportation. There were 139 grants and 98 denials. Additionally, 16 applicants are pending and 4 are being held until necessary documentation is received. Of the 98 applicants denied relief, the number who were felons rather than misdemeanants is uncertain. Office of Public Information, Georgia Board of Pardons and Parole, June 4, 2001, facsimile communication to the 
author. Other than explaining its policy of granting pardons to misdemeanant immigrants with otherwise clean records, the Board has not made public its reasons for grants and denials. Interview with Walt Davis, supra note 13.

${ }^{15}$ The Board does not ordinarily consider granting par. dons to misdemeanants because a misdemeanor conviction does not deprive a person of any civil rights. Interview with Walt Davis, supra note 13 . The purpose of the eligibility waiting period is to give a pardon applicant time to show that he can remain law-abiding, and to demonstrate his rehabilitation and good character.

${ }^{16}$ See supra note 10.

${ }^{17}$ Office of Public Information, Board, facsimile com. munication to author, May 31, 2001.

${ }^{18}$ Mark Bixler, Unified Front; City's Korean Residents Rally to Fight Man's Deportation, ATLANTA JouRnAl ANd CONSTITUTION, Feb. 17, 2000, at 14A ("United Front"); Mark Bixler, Forgiven Felon is Now Free to Stay, ATLANTA JourNAL AND CONSTITUTION, April 25, 2000 at 1 A.

${ }^{19}$ Park was technically ineligible to apply for a pardon in the ordinary course because he had not satisfied the Board's 5-year waiting period. But the Korean churches and business community circulated peti. tions calling upon the Board to pardon Park. His victim, although he had been deprived of partial sight in one eye as a result of being kicked by Park, forgave Park and wrote to the Board asking that Park be pardoned. See Bixler, "United Front," supra note 18.

${ }^{20}$ State of Georgia Board of Pardons, Other Forms of Executive Clemency (June 1, 2001), available at http://www.pap.state.ga.us/history.html.

${ }^{21}$ See Interview with Walt Davis, supra note 7.

${ }^{22}$ Mark Bixler, Law Tells Immigrants Guilty Plea Can Mean Deportation, AtLANTA JouRnal ANd Constitution, May 9 , 2000 , at $5 \mathrm{~B}$. The law became effective on June 1, 2000. Fourteen other states and the District of Columbia have enacted similar laws.

${ }^{23}$ State v. Colack, 273 Ga. 361, 541 S.E. 2d 374 , (2001). The Gwinnett County judge ruled that Calvin James Colack's guilty plea was not entered voluntarily because he was not advised of the collateral conse. quence of deportation. Colack's sentence was reduced to avoid deportation.

${ }^{24}$ See Bixler, supra note 22.

${ }^{25}$ Interview with Walt Davis, supra note 7.

${ }^{25}$ Letter From Walter S. Ray, Bobby K. Whitworth, Garfield Hammonds Jr., Dr. Betty Ann Cook, \& Dr. Eugene P. Walker, State Board of Pardons and Paroles, to Senator Max Cleland (March 4, 2000).

${ }^{27}$ Interview with Walt Davis, supra note 7.

${ }^{28}$ In April 2001, the government argued before the Supreme Court in two cases originating in the Second Circuit that an alien subject to removal had no right to review in any forum. While the Attorney General retains the discretion under IIRAIRA to waive deporta. tion, he need not consider such appeals. The government argued that the power of the Attorney General to relieve an alien of the consequences of an order of deportation was akin to the President's pardon power, an act of grace. Transcript of Oral Argument before the Supreme Court, Calcano-Martinez v. Immigration and Naturalization Service, 2001 WL 469078. Tran. script of Oral Argument before the Supreme Court, Immigration and Naturalization Service v. St. Cyr, 2001 WL 469077. See also Brief for the Petitioner,
Immigration and Naturalization Service v. St. Cyr, 121 S.Ct. 848 (mem) (229 F. 3d 406) (No. 00-767) and Brief for the Respondent, Calcano-Martinez v. Immigration and Naturalization Service, 121 S. Ct. 849 (232 F. 3d 328) (No. 00-1011).

On June 25, 2001, the Supreme Court handed down INS v. St.Cyr, No 00-767, 2001 WL 703922 (June 25, 2001), and Calcano-Martinez v. INS, No. 7039433 (June 25,2001). The Court affirmed the Second Circuit's judgment in both cases that district courts may hear habeas petitions from aliens seeking relief from final orders of removal. INS v. St. Cyr also affirmed that aliens who pled guilty before the 1996 amendments took effect remain eligible for discretionary relief from an order of deportation available at the time of the plea.

${ }^{29}$ The INS has affirmed that its officials have prosecutorial discretion not to initiate removal proceedings in cases involving minor crimes and/or substantial hardships. Memorandum from Doris Meissner, Commissioner, Immigration and Naturalization Service, U.S. Department of Justice, to Regional Directors, District Directors, Chief Patrol Agents, Regional and District Counsel (Nov. 17, 2000) (on file with the author). Although the ins confirmed that its estimate of the number of permanent resident misdemeanants deported in FY 2000 was on the order of several hum. dred, the Office of Public Affairs had no information about the impact of Commissioner's Nov. 17, 2000, Memorandum on the number of deportations of mis. demeanants. Telephone interview with Bill Strassberger, INs Office of Public Affairs (June 12, 2001).

${ }^{30}$ There are of course instances of federal mass pardons and amnesties of the "political" variety, granted to heal social divisions and conflicts, such as Presi. dent Carter's amnesty of Vietnam War draft evaders. These avowedly "political" uses of the clemency power are distinct from the kind of mass clemencies discussed in this article, although surely the distinc. tion between political and nonpolitical uses of the clemency power can be overdrawn and even illusory.

${ }^{31}$ James D. Barnett, The Grounds of Pardon, $17 \mathrm{~J}$. CRIM. L. \& CRIMInology 490, 514 (1927). Donaghey was governor of Arkansas from 1909-13.

${ }^{32}$ Stuart Taylor, All the President's Pardons: The Real Scandal, NaT'L J., Oct. 30, 1999, at 316.

${ }^{33}$ Toney Anaya, Statement of Toney Anaya on Capital Punishment, 27 U. RicH. L. REv. 177 (1993).

${ }^{34}$ See Daniel T. Kobil, The Quality of Mercy Strained: Wresting the Pardon Power from the King, 69 TEX. L. Rev. 569,629 (1991).

${ }^{35}$ Linda L. Ammons, Discretionary Justice: A Legal and Policy Analysis of a Governor's Use of the Clemency Power in the Cases of Incarcerated Battered Women, 3 J.L. \& POL'Y 1, 3-4 (1994).

${ }^{36}$ Technically removal proceedings are not criminal; removal is a civil correction of an ongoing violation of immigration law. Yet these deportation pardons function like commutations of sentence because they relieve the grantees of a severe collateral conse. quence, penal in all but name, and evocative of the ancient punishment of banishment. See Gabriel J. Chin \& Richard W. Holmes, Jr., Effective Assistance of Counsel and the Consequences of Guilty Pleas, 87 CoRNELL L. REV. (forthcoming 2002) (criticizing current legal doctrine regarding the distinction between direct and collateral consequences of a guilty plea). 